\title{
The Impact of Internal Control Weaknesses on Firms' Cash Policies
}

\author{
Mikhail Pevzner* \\ Merrick School of Business \\ University of Baltimore \\ mpevzner@ubalt.edu \\ Gregory Gaynor \\ Merrick School of Business \\ University of Baltimore \\ ggaynor@ubalt.edu
}

June 23, 2015

*Corresponding author. We express our sincere thanks to Prof. Sharad Asthana, the editor, and to the anonymous reviewers. Pevzner gratefully acknowledges the assistance of the EY Chair in Accounting at the University of Baltimore. The initial phase of this research was conducted while Pevzner was on the faculty at the School of Management in George Mason University. 


\section{The Impact of Internal Control Weaknesses on Firms' Cash Policies}

We study the association between firms' Section 302 and Section 404 internal control weaknesses and these firms' cash-to-cash flows sensitivities. We also examine whether the presence of the internal control weaknesses affects the relationship between firms' asset liquidity and stock liquidity. We find that the presence of Section 404 internal control weaknesses is associated with stronger cash-to-cash flows sensitivities and with weaker impact of higher asset liquidity on stock liquidity. Our results suggest that internal control weaknesses increase firms' reliance on internal, as opposed to external, financing. Also, internal control weaknesses increase uncertainty over future uses of cash, thereby reducing the positive impact of higher relative cash balances on stock liquidity. Thus, our study provides additional evidence on the potential costs of internal control weaknesses.

JEL Classification: M40, M41, M42

Key words: Cash, Internal Control Weaknesses, Liquidity

Data availability: All data is available from public sources identified in the text. 


\section{Introduction}

"Cash is king" is a common adage. It captures the notion that a firm's ability to generate positive operating cash flows, as well as its ability to access cash, improves its future viability. Firms can benefit by carrying larger cash balances because it may demonstrate to the market that the firm exercises a more judicious investment and spending policy. Hence, the level of cash holdings is often positively associated with stock liquidity (Gopalan et al. 2012), and can make it less costly for firms to raise external financing (Amihud and Mendelson, 1986). However, there may be disadvantages to holding large cash balances. The stockpiling of cash, instead of its deployment into potentially valuable investment opportunities, may impede a firm's future growth (Almeida et al. 2004). Firms' cash balances rose during the recent financial turmoil, reaching an unprecedented aggregate level of \$1.91 trillion dollars as of June 2010 (Lahart 2010). This cash hoarding is frequently blamed for the slow rate of economic recovery in the aftermath of the Financial Crisis of 2008-2009, since companies have been saving their cash rather than investing it in new machinery and equipment, hiring workers, or otherwise growing their manufacturing capacity (Lahart 2010). However, while cash hoarding can be due to firms' unwillingness to invest due to high market uncertainty, it could also be driven by firms' precautionary savings policies due to their perceived inability to raise external capital in the future. Firms' heavy dependence on internal cash for financing could have a negative effect on their future prospects. The inability to access external capital markets and the need to rely on internal financing potentially impairs firms' ability to pursue positive NPV projects when internal cash balances are inadequate due to, for example, external economic shocks.

While the literature offers different explanations for firms' excessive reliance on internal financing (such as financing constraints due to smaller size, younger age, or lack of credit rating), in this paper we examine the impact of firms' Section 302 and Section 404 reported internal control material weaknesses (hereafter ICW) on firms' reliance on internal financing. Section 404 internal control audits, in particular, add substantial costs to firms ${ }^{1}$. We believe our examination of the effect of Section 302 and 404 ICWs on firms' financing policies contributes to the ongoing debate regarding the costs and benefits that these audits bring to the capital markets.

\footnotetext{
${ }^{1}$ See, for example, a relevant SEC study of SOX costs at: https://www.sec.gov/spotlight/soxcomp/soxcomp-all-attach.pdf
} 
The Sarbanes Oxley Act requires ICW reporting and applies to all firms for Section 302 ICWs (management reported weaknesses) and larger accelerated filer firms for Section 404 ICWs (auditor reported weaknesses). ${ }^{2}$ ICWs represent signals that firms' internal control systems may not prevent a material accounting misstatement from occurring in the future. Because such misstatements can be very costly to firms and their investors, the disclosure of ICWs can, themselves, generate negative capital market reactions. An extensive body of auditing literature examines both the determinants of ICWs and their impact on firms. Evidence suggests that firms with more complex operations, accounting systems and/or lower overall accounting quality are more likely to report ICWs ${ }^{3}$. Moreover, the presence of ICWs has been shown to be associated with numerous factors that may negatively affect firms' ability to access external financing, including 1) a negative market reaction to their disclosure $\left.^{4}, 2\right)$ a higher cost of equity and debt capital ${ }^{5}$, 3) lower CFO cash compensation ${ }^{6}$, 4) higher turnover of corporate directors $\left.^{7}, 5\right)$ lower creditor recoveries ${ }^{8} ; 6$ ) higher profitability of insider trades ${ }^{9}, 7$ ) higher audit fees ${ }^{10}$; 8) more restrictive debt covenants ${ }^{11}$; and 9) lower assessment of creditworthiness ${ }^{12}$.

Given these prior results, it is natural to expect that ICWs will impair firms' ability to raise external capital. However, measuring the overall impact of ICWs on firms' financing options and policies is made more complex by the existence of two categories of ICWs: 1) those reported by management (Section 302 ICWs); 2) those reported by auditors (Section 404 ICWs). Moreover, while Section 302 ICW disclosures are required of all firms, Section 404 ICW disclosures apply only to accelerated filers. In addition, Section 302 ICWs are reported quarterly but Section 404 disclosures are reported annually (Hammersley et al. 2008). Thus, the impact on firms may be different for each type of ICWs. Prior research shows mixed results as to which type(s) of ICWs may cause sufficient negative reaction among external stakeholders to prompt a firm to rely more on internal

\footnotetext{
${ }^{2}$ For example, see further discussion in Hammersley, Myers and Shakespeare (2008) and SEC guidance at: https://www.sec.gov/rules/final/2010/33-9142.pdf .

${ }^{3}$ Ashbaugh-Skaife, Collins, and Kinney (2007); Ge and McVay (2005); Doyle, Ge and McVay (2007a); Doyle, Ge and McVay (2007b)

${ }^{4}$ Kim and Park (2009); Beneish, Billings, and Hodder (2008); Hammersley, Myers, and Shakespeare (2008)

${ }^{5}$ Ashbaugh-Skaife, Collins, Kinney and LaFond (2009); Dhaliwal, Hogan, Trezevant and Wilkins (2011)

${ }^{6}$ Hoitash, Hoitash and Johnstone (2012)

${ }^{7}$ Johnstone, Li and Rupley (2011)

${ }^{8}$ Tang, Tian and Yan (2012)

${ }^{9}$ Ashbaugh-Skaife, Veenman and Wangerin (2013)

${ }^{10}$ Hoitash, Hoitash, and Bedard (2008); Raghunandan and Rama (2006)

${ }^{11}$ Castello and Wittenberg-Moerman (2011); Kim, Song, and Zhang (2011)

${ }^{12}$ Schneider and Church (2008)
} 
financing. For example, Beneish, Billings and Hodder (2008) do not find that the market reacts to Section 404 ICWs, possibly because the information in auditor reports is preempted by the disclosure of Section 302 ICWs. Alternatively, Section 404 ICWs are reported as a result of specific internal control audits, and thus could be perceived as more relevant by the outside financing parties. ${ }^{13}$ Therefore, in our study, we examine separately the impact of both types of ICWs on cash-to-cash flow sensitivities and on the relation between cash and external stock liquidity.

More specifically, we investigate how ICWs impact firms' cash-to-cash flow sensitivities and the relationship between the cash liquidity of a firm's assets and its stock liquidity. Firms' cash-to-cash flow sensitivities capture their reliance on the internal, as opposed to external, sources of financing, i.e. firms' tendency to "hoard cash" (Almeida et al. 2004). The relationship between a firm's cash balance and its stock liquidity captures the potential positive effect of stockpiling cash on the stock liquidity, and, thus, on the cost of external financing. Our investigation of the effects of ICWs on these two relationships allows for a clearer understanding both of how ICWs impact firms' propensity to save internally generated cash flow and of how these retained cash balances affect firms' stock liquidity, a key determinant of firms' cost of capital.

We use data from Compustat, CRSP, IBES, and Audit Analytics between 2005 and 2010 to show that the presence of Section 404, but not section 302, ICWs is associated with stronger cash-cash flow sensitivities and a weakened positive impact of cash on stock liquidity. Our conclusions remain unaffected after controlling for endogenous determinants of ICWs indicated in the prior literature. Our study complements prior literature by showing that, in addition to other negative effects that prior work documents, poor internal controls can reduce firms' access to external capital and prompt greater reliance on internally generated cash flows. In addition, our results are consistent with the view that there is a higher perceived credibility in a 404 ICW disclosure than in a 302 ICW disclosure.

For the purposes of our study, the findings of the ICW literature have two main implications. First, given that ICWs constrain firms' external financing ability (Ashbaugh-Skaife et al. 2009), it is natural to suggest that

\footnotetext{
${ }^{13}$ This is consistent with the results of Lopez, Vandervelde and $\mathrm{Wu}$ (2009), who find that the auditor's opinion on internal controls provides financial statement users with value-relevant information.
} 
these firms would use more internal financing. However, this reasoning implicitly assumes that firms want to pursue the same investment opportunities that would otherwise be available to them had they had greater access to external financing. Instead, the stockpiling of cash and emphasis on internal financing may be accompanied by a reduced number of investment options for the firm and, ultimately, a reduction in aggregate investment.

Therefore, we believe that the examination of the relationship between ICWs and firms' cash policies is important because of the potential macro-economic impact of lower overall investment among firms. It is unclear whether the reliance on internal financing through more extensive savings of operating cash flow results in a more efficient use of cash resources. Therefore, we investigate the effect that reliance on internal cash has on firms' financing decisions. In addition, we examine how the stock market, through the prism of stock liquidity, perceives the firm's future expected use of cash when internal control weaknesses are present. Our research contributes to the debate on the effect of internal control weaknesses on firms' financing costs. ${ }^{14}$ By finding greater reliance on internal financing in the presence of ICWs, we provide additional evidence that internal control weaknesses increase the relative costs of external financing. The tendency of firms with ICWs to rely more on internal financing could have macro-economic implications since such firms may be inclined to hoard cash and invest less overall than they might otherwise have if their access to the external markets was not impaired. This effect may, at times, provide an additional explanation for the observed increase in some firms' cash balances.

We contribute to the literature on internal control weaknesses as well as to the research concerning firms' cash policies. While prior literature examines the various effects of ICWs' on firm policies, we are not aware of any prior study that addresses the impact of ICWs on firm cash policies. We believe that our study is important given the recent public policy concerns regarding companies accumulating abnormally large cash balances, which some suggest has contributed to lower macro-economic growth. ${ }^{15}$ Our study describes a possible reason why some firms have to rely on internally-generated cash (and large cash balances), namely because they may be limited in their ability to raise external cash due to poor internal controls. Prior work has broadly shown that ICWs are associated with greater firm uncertainty. By providing additional evidence of the effects of internal

\footnotetext{
${ }^{14}$ For example, prior work also suggests that the observed negative effects of ICWs on external financing costs could be caused by other firm level characteristics (Ogneva, Subramanyam and Raghunandan 2007). Similarly, Ghosh and Lee (2013) show that market reaction to ICWs disclosures is muted because of confounding by other firm characteristics associated with ICWs.

${ }^{15} \mathrm{http}: / /$ www.thewire.com/business/2014/01/companies-hoard-cash-trillion/357254/
} 
control weaknesses on firms' cash policies, we implicitly bolster the argument in the literature that ICW reports have their own information content, incremental to the effects of the observed firm characteristics. We also contribute to the debate on the consequences of the Sarbanes Oxley Act (SOX), which instituted the requirement of periodic managerial assessments of internal controls and internal control audits. Our results suggest that internal control audits provide useful information to the capital markets that can affect firm behavior.

The rest of this paper is organized as follows. The next section provides a discussion of background literature and develops our testable hypotheses. Section 3 describes our research methodology and sample. In Section 4, we analyze our results. Section 5 concludes.

\section{Literature Review and Hypotheses Development}

\subsection{Background on Cash Flow Sensitivity of Cash}

An extensive body of finance literature examines how financing constraints impact firms' cash behavior. The general theme of that literature is that financially constrained firms (in particular, younger and smaller firms (Beck, Demirguc-Kunt, Laeven, Maksimovic, 2006) have to rely more on internally generated cash in order to sustain their operations and growth. One measure of firms' reliance on internal finance is a firm's cash-to-cash flows sensitivity (Almeida, Campello and Weisbach, 2004). Cash-to-cash flows sensitivity measures a firm's tendency to save an extra dollar of a firm's operating cash flow in a firm's cash balance, i.e. it is a measure of a firm's precautionary savings' propensity. It is represented by the slope coefficient in the regression of the annual change in cash balance on that year's operating cash flow. The more positive this coefficient is, the greater is the sensitivity of a firm's cash balance to its operating cash flow level. ${ }^{16}$ When a firm has greater freedom to raise cash externally, its cash balance is more likely to be driven by changes in financing, but not in operating, cash flow. Greater reliance on internal cash financing is costly because the rates of return on cash balances are typically low. Therefore, it is often suggested that, ideally, firms should either reinvest their operating cash flows in positive NPV projects or return the extra operating cash flows to shareholders. Thus, firms that have greater difficulty raising cash externally will rely more on internal financing and exhibit higher cash-to-cash flow sensitivities. Consistent

\footnotetext{
16 This would be coefficient $\mathrm{a}_{2}$ in our models $1 \mathrm{a}$ and $1 \mathrm{~b}$.
} 
with this notion, prior work shows that financially constrained firms (i.e. firms that tend to be smaller or younger) experience greater cash flow sensitivity of cash, and that better-functioning capital markets with greater levels of financial development result in lower cash-to-cash flow sensitivities (Almeida, Campello and Weisbach, 2004;

Khurana, Martin, Pereira, 2006). Interestingly, positive cash-to-cash flow sensitivity has also been shown to exist in both constrained and unconstrained firms in Taiwanese firms (Lin, 2007) which suggests that other institutional mechanisms affect cash-to-cash flow sensitivity; this is consistent with the result in Khurana et al. (2006) who show that financial market development relaxes this sensitivity.

\subsection{Background on Internal Control Weaknesses}

Under Section 302 (5) of the Sarbanes-Oxley Act, managers of the firm are required to certify quarterly that "the signing officers have disclosed to the issuer's auditors and the audit committee of the board of directors (or persons fulfilling the equivalent function)... all significant deficiencies in the design or operation of internal controls which could adversely affect the issuer's ability to record, process, summarize, and report financial data and have identified for the issuer's auditors any material weaknesses in internal controls." ${ }^{17}$ Thus, Section 302 management-reported ICWs are based on internal management's assessment of controls and are typically reported quarterly. Section 404 of SOX requires that "a publicly-held company's auditor to attest to, and report on, management's assessment of its internal controls." 18 Internal control audits are conducted annually, and apply only to accelerated filers (i.e. SEC registrants with the public float in excess of $\$ 75$ million). The Public Companies Accounting Oversight Board (PCAOB) has continued their strong emphasis on the importance of the internal control audits to capital market participants. For example, PCAOB board member Jeanette Franzel said in a March 2014 speech:

"Unfortunately, over the decades, we've seen multiple cycles in which company management and internal and external auditors simply didn't get it right in the area of internal control, resulting in failures to effectively define, understand, implement, and assess internal control. Currently, after more than a decade of implementation of the internal control requirements of the Sarbanes-Oxley Act, we are faced with an opportunity to take a fresh look at internal control over financial reporting to prevent and detect material misstatements, and protect investors. This fresh look necessarily will involve management, internal auditors, external auditors, audit committees, and the PCAOB working together constructively to fulfill our respective responsibilities in the system of assurance over financial reporting"'19.

\footnotetext{
${ }^{17} \mathrm{http}: / /$ www.sox-online.com/act_section_302.html

${ }^{18} \mathrm{http}: / / \mathrm{www}$.aicpa.org/advocacy/issues/pages/section404bofsox.aspx

${ }^{19}$ http://pcaobus.org/News/Speech/Pages/03262014_IIA.aspx
} 
Recent reports suggest that continued PCAOB emphasis on the audits of internal controls has led to overall improvements in the quality of internal control audits ${ }^{20}$. In this spirit, our study contributes to the understanding of the broad consequences of internal control audits to the capital markets and firms' financing policies.

\subsection{Relationship between ICWs and Reliance on Internal Financing}

Evidence suggests that firms with more uncertain and complex operations are more likely to have ICWs. Doyle, Ge and McVay (2007a) document that smaller firms, firms with foreign operations, higher sales growth and/or the presence of restructuring of operations are more likely to disclose Section 302 ICWs. Such firms are also likely to have lower accrual quality (Doyle, Ge, and McVay, 2007b). Chan et al. (2007) provide some evidence that Section 404 ICWs are associated with more positive discretionary accruals. Furthermore, the presence of Section 404 ICWs is associated with an increased cost of debt capital (Ashbaugh-Skaife et al. 2009, Dhaliwal et al. 2011) and with less precise earnings guidance (Feng, Li and McVay, 2009). Section 302 ICWs are associated with less reliance by creditors on accounting-based debt covenants and a higher cost of private debt (Castello and Wittenberg-Moerman, 2011). Because ICWs are associated with higher costs of external financing, the presence of ICWs may prompt firms to rely more on internal financing sources, including cash flows from operations. Thus, the presence of ICWs may increase these firms' reliance on internally-generated cash flows, prompting them to keep even larger cash balances and contribute to the negative effects of cash hoarding. A priori, both Section 302 ICWs (reported quarterly by management), and Section 404 ICWs (uncovered in the course of internal control audits) could have similar effects on firms' cash policies, as both have been shown to have negative stock market effects (e.g. Hammersley et al. 2008; Ashbaugh-Skaife et al. 2009). However, it is important to examine their effect together in the same regression model because Section 302 ICWs are based on internal management assessment, which is likely to be more subjective and potentially opportunistic, while Section 404 ICW disclosures are provided by independent auditors. Because external financing sources are more likely to rely on the audit opinion as an indicator of seriousness of the internal control problems, it is possible that the impact of 302 and 404 ICWs on cash flow sensitivity of cash will be different. Therefore, our predictions relate to both Section 302 and Section 404 ICWs. This leads us to the following hypothesis:

\footnotetext{
${ }^{20}$ http://blogs.wsj.com/cfo/2015/06/04/big-firms-getting-better-grades-on-internal-control-auditspcaob/?KEYWORDS=internal+control+pcaob
} 
Hypothesis 1: The presence of either Section 302 or Section 404 ICWs is associated with a higher sensitivity of cash holdings to internally generated cash flows.

\subsection{Impact of ICWs on the Relationship between Cash Liquidity and Stock Liquidity}

Besides possibly causing reduced access to external capital, the presence of ICWs raises potential concerns with respect to the firms' use of its existing cash resources. Literature suggests that ICWs are associated with less precise management forecasting policies (Feng et al. 2009) and less efficient inventory management (Feng et al. 2012). Cheng et al. (2013) find that ICWs are associated with sub-optimal investment policies in the period prior to their disclosure. More broadly, Ashbaugh et al. (2009) find that internal control deficiencies are associated with higher idiosyncratic risk for firms. Thus, even though a firm's cash balance could be viewed by the market as a sign of financial health, these results also suggest that the presence of ICWs could increase uncertainty regarding a firm's intended use of cash. For example, the lack of good forecasting systems could increase the likelihood that a firm may invest its cash in sub-optimal projects. Hence, the presence of such uncertainty may overshadow any positive effect of cash savings on the market's expectations of a firm's future viability. Consistent with this argument, Gopalan, Kadan and Pevzner (2012) find that firms with higher retained cash balances (higher asset liquidity) enjoy higher stock liquidity (lower stock illiquidity), but this relationship is weakened when the uncertainty concerning the use of a firm's cash increases. This result suggests that when higher ex-ante uncertainty over future uses of cash is present, the positive effect of asset liquidity on stock liquidity is attenuated. Hence, if weaker internal controls raise concerns over how cash will ultimately be spent (for example, whether it could be wasted in the future), the presence of internal control weaknesses will reduce any valuation benefits of extra cash savings. However, it is also possible that the market will rely more on the availability of cash balances when internal control weaknesses are present. In other words, in this case, the availability of cash becomes a more salient signal of future firm performance, and in and of itself helps resolve future uncertainty over firm prospects. Consistent with this view, Charoenwong, Chong, and Yang (2014) show that asset liquidity becomes more important in determining stock liquidity in the countries with more poor information environments. Hence, it is possible that the presence of ICWs may either strengthen or attenuate the 
relationship between cash balances and stock liquidity. Because both Section 302 IWCs and Section 404 ICWs

could impact the information environment differently (with Section 404 possibly having a stronger effect due to auditors' higher perceived credibility), it is possible that both Section 302 ICW and Section 404 ICW could impact the relation between cash liquidity and stock liquidity. Hence, we make the following two-sided prediction:

Hypothesis 2: The presence of either Section 302 or Section 404 ICWs affects the relationship between asset liquidity and stock liquidity.

\section{Research Design}

Consistent with prior literature, in our study we distinguish between Section 302 ICWs (managementreported) and Section 404 ICWs (auditor-reported). We examine the impact of both types of ICWs on firms' cash flow sensitivity of cash and on the previously documented relation between firms' asset liquidity and stock liquidity. To test the effects of internal control weaknesses on cash flow sensitivity of cash, we modify a regression model of cash flow sensitivity of cash to include ICWs as follows:

$\triangle C A S H_{t}=a_{0}+a_{1} * W E A K+a_{2} * C F O_{t}+a_{3} * C \boldsymbol{F O} \boldsymbol{O}_{t}^{*} \mathbf{W E A K}+a_{4} * L M V E_{t-1}+a_{5} * C F O_{t} * L M V E_{t-1}+a_{6} * L A G E_{t}+$

$a_{7} * C F O_{t} * L A G E_{t}+a_{8} *$ TOBIN $_{t}+e$

Where $\triangle C A S H_{t}$ is an annual change in a firm's cash balance, $C F O_{t}$ is a firm's annual operating cash flow, WEAK denotes an indicator variable one if a firm reports Section 302 (or Section 404) internal control weakness in the current or preceding two years. Our primary coefficient of interest is $\boldsymbol{a}_{3}$ which we expect to be positive if the presence of ICWs increases firms' financing constraints and, thus, prompts greater savings of cash from internally generated cash flows. We also control for firm size $\left(L M V E_{t-1}\right)$, age $\left(L A G E_{t}\right)$, and interactions of $C F O_{t}$ with those variables because prior literature suggests that firm size and age help determine the level of financing obstacles a firm faces (Beck et al. 2006). Consistent with prior literature, we also include TOBIN's Q $\left(T O B I N_{t}\right)$ as a control variable in our regression model. The detailed definition of these variables is provided in the Appendix.

Prior literature suggests that firms with more complex operations and firms experiencing financial performance problems are more likely to report internal control weaknesses. This potentially introduces 
endogeneity in our regression models and, therefore, we include ICW determinants identified in the prior literature as additional control variables in an expanded regression model below. All of these additional control variables are defined in the Appendix.

$$
\begin{aligned}
& \triangle C A S H_{t}=a_{0}+a_{1} * W E A K+a_{2} * C F O_{t}+a_{3} * C F \boldsymbol{O}_{t} * \mathbf{W E A K}+a_{4} * L M V E_{t-1}+a_{5} * C F O_{t} * L M V E_{t-1}+a_{6} * L A G E_{t}+ \\
& a_{7} * C_{F} O_{t} * L_{A G E}+a_{8} * \text { TOBIN }_{t}+a_{9} * L_{S E G M}+a_{10} * C F O_{t} * L_{S E G M}+a_{11} * \triangle S A L E_{t}+a_{12} * C F O_{t} * \triangle S A L E_{t}+ \\
& a_{13} * \text { FOREIGN } N_{t}+a_{14} * \text { CFO }_{t} * \text { FOREIGN }_{t}+a_{15} * M A_{t}+a_{16} * C_{F} O_{t} * M A_{t}+a_{17} * \text { RESTRUCTURE }_{t}+ \\
& a_{18} * C^{2} O_{t} * R_{\text {RSTRUCTURE }}+a_{19} * I N V T_{t}+a_{20} * C F O_{t} * I N V T_{t}+a_{21} * A R_{t}+a_{22} * C F O_{t} * A R_{t}+a_{23} * B 5+a_{24} * C F O_{t} * B 5+ \\
& a_{25} * \text { RESTATE }_{t}+a_{26} * \text { CFO }_{t} * \text { RESTATE }_{t}+a_{27} * \text { STDRET }_{t}+a_{28} * \text { CFO }_{t} * \operatorname{STDRET}_{t}+a_{29} * \operatorname{LOSS}_{t}+a_{30} * \mathrm{CFO}_{t} * \mathrm{LOSS}_{t}+ \\
& a_{31} * \Delta E A R N_{t}+a_{32} * C F O_{t} * \Delta E A R N_{t}+a_{33} * \Delta A L T M A N_{t}+a_{34} * C F O_{t} * \Delta A L T M A N_{t}+a_{35} * L E V_{t}+a_{36} * C F O_{t} * L E V_{t}+e
\end{aligned}
$$

Gopalan, Kadan and Pevzner (2012) show that: 1) higher cash balances are associated with lower levels of Amihud (2002) stock Illiquidity (i.e. higher levels of firm liquidity), ${ }^{21}$ and 2) the negative relationship between cash balances and Amihud stock Illiquidity is weakened (i.e. becomes more positive) for firms with higher financing constraints, higher growth options, and higher information uncertainty; i.e. these factors reduce positive impact of cash on firms' liquidity. Because we expect that ICWs increase firms' financing constraints and uncertainty over firms' future uses of cash, we expect that ICWs will weaken the positive impact of firms' cash on their stock liquidity (increase impact of firms' cash on their illiquidity).

To test this prediction, we run the following regression models:

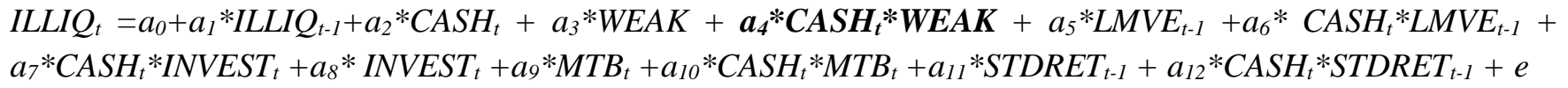

Where $I L L I Q_{t}$ is Amihud Illiquidity, $C A S H_{t}$ is a firm's cash balance, WEAK is an indicator variable for 302 or 404 ICW defined above; other control variables, such as size $\left(L M V E_{t-1}\right)$, market-to-book ratio $\left(M T B_{t}\right)$ and volatility of daily stock returns in the prior year $\left(S T D R E T_{t-1}\right)$ are included to control for the impact that a firm's financing constraints and information uncertainty have on the relationship between a firm's cash balance and Amihud Illiquidity identified in Gopalan, Kadan and Pevzner (2012) and in Charoenwong, Chong, and Yang (2014). We

\footnotetext{
${ }^{21}$ This result is confirmed in Charoenwong, Chong, and Yang (2014) in an international setting.
} 
also control for prior year Illiquidity $\left(I L L I Q_{t-1}\right)$ to isolate the impact of other potentially time-invariant firm characteristics on firms' liquidity. Our primary coefficient of interest is $\boldsymbol{a}_{4}$ which we expect to be positive if the presence of ICWs reduces the positive impact of cash on firms' stock liquidity. We provide a detailed definition of all variables in the Appendix.

Similar to equation (1B) above, we also control for any potential endogenous determinants of ICWs identified in prior literature in the expanded model below:

$I L L I Q_{t}=a_{0}+a_{1} * I L L I Q_{t-1}+a_{2} * C_{A S H}+a_{3} * W E A K+a_{4} * C_{A S H} * W E A K+a_{5} * L M V E_{t-1}+a_{6} * C A S H_{t} * L M V E_{t-1}+$ $a_{7} * \mathrm{CASH}_{t} * \mathrm{INVEST}_{t}+a_{8} * \mathrm{INVEST}_{t}+a_{9} * \mathrm{MTB}_{t}+a_{10} * \mathrm{CASH}_{t} * \mathrm{MTB}_{t}+a_{11} * \mathrm{STDRET}_{t-1}+a_{12} * \mathrm{CASH}_{t} * \mathrm{STDRET}_{t-1}+$

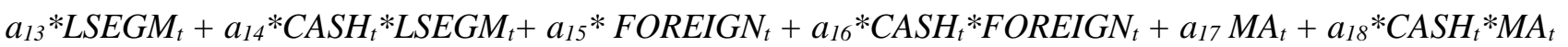
$+a_{19} * R_{\text {RSTRUCTURE }}+a_{20} * \mathrm{CASH}_{t} *$ RESTRUCTURE $_{t}+a_{21} * \Delta S A L E_{t}+a_{22} * \mathrm{CASH}_{t} * \Delta S A L E_{t}+a_{23} * I N V T_{t}+$ $a_{24} * \mathrm{CASH}_{t} * I N V T_{t}+a_{25} * A R_{t}+a_{26} * \mathrm{CASH}_{t} * A R_{t}+a_{27} * \mathrm{LOSS}_{t}+a_{28} * \mathrm{CASH}_{t} * \mathrm{LOSS}_{t}+a_{29} * \Delta E A R N_{t}+$ $a_{30} * C_{A S H} * \Delta E A R N_{t}+a_{31} * \triangle A L T M A N_{t}+a_{32} * C_{t} A S H_{t} * \Delta A L T M A N_{t}+a_{33} * L A G E_{t}+a_{34} *$ CASH $_{t} *$ LAGE $_{t}+a_{35} * B 5$ $+a_{36} * C_{A S H} * B 5+a_{37} * R_{t} E S T A T E_{t}+a_{38} * C_{A S H} * R_{t} E S T A T E_{t}+a_{39} * L E V_{t}+a_{40} * C_{A S H} * L_{t} V_{t}+e$

We include year and industry fixed effects in our regression models, and cluster our standard errors at the firm level per Petersen (2009). All continuous variables are winsorized at the $1^{\text {st }}$ and $99^{\text {th }}$ percentiles.

\section{Results}

\subsection{Sample and Descriptive Statistics}

To construct our sample, we require ICW data from Audit Analytics as well as data from Compustat and CRSP to estimate our control variables. This results in a sample of 10,214 observations covering the period of 2005-2010. Panel A of Table 1 provides summary statistics for variables in our sample. We note that approximately $23 \%$ of the observations in our sample report Section 302 ICW in the current or preceding two years, and approximately $12 \%$ of the observations in our sample report Section 404 ICW in the current or preceding two years. Mean (median) operating cash flows (CFO) of firms in our sample is 0.04 (0.08), suggesting that our sample is not biased towards unhealthy firms; this is consistent with average positive sales growth of firms in our sample, corresponding to mean (median) $\triangle$ SALE of $9 \%(6 \%)$. Mean (median) size of 
firms in our sample (LMVE) is 5.95 (5.91), suggesting that our sample is made up of predominantly larger firms, likely an outcome of data selection procedures requiring data availability from Audit Analytics, CRSP and Compustat. Mean (median) MTB is 2.75 (1.98), suggesting the presence of higher growth firms in our sample. Panel B of Table 1 reports the annual distribution of firms in our sample; we note no significant clustering of firms in any particular year in our sample. Similarly, we note no significant clustering of firms by industry in Panel C of Table 1. Table 2 reports Pearson correlations among variables in our sample. We note that, as expected, WEAK (302) and WEAK (404) variables are highly positively correlated. The negative correlation of LMVE and WEAK (302) suggests that larger firms are less likely to report ICWs. Other correlations are consistent with expectations.

\subsection{Multivariate Analyses Results}

Panel A of Table 3 reports the estimation of Models 1A and 1B for Section 302 ICWs. We note that coefficient $a_{3}$ is not significant in either Model $1 \mathrm{~A}$ or $1 \mathrm{~B}$ at the $5 \%$ significance level. It may be the case that management-reported Section 302 ICWs lack the necessary credibility to significantly affect a firm's access to external financing and, therefore, do not affect its reliance on internal financing. However, the lack of results here could also be the result of sample selection procedures biasing our sample towards healthier firms. In untabulated results, when we consider only data requirements for the analysis in Table 3 (a sample size of about 18,000 observations), we find coefficient $a_{3}$ to be statistically significant in Model $1 \mathrm{~A}$ at the $5 \%$ significance level.

In Panel B of Table 3, we examine the impact of Section 404 ICWs on firms' cash-to-cash flows sensitivities. Consistent with Hypothesis 1, we find $a_{3}$ to be positive and significant in both Models $1 \mathrm{~A}$ and 1B, suggesting that the presence of Section 404 ICWs increases firms' tendency to save internally generated cash flow through an increased reliance on internal financing. The combined results in Panels A and B are consistent with the view that auditor-generated Section 404 ICWs are more credible than are management-reported Section 302 ICWs and, therefore, have a greater effect on the behavior of external stakeholders and, ultimately, the firm itself. It is worth noting that our ability to find the result in Model 1B suggests that these results are not likely to be driven by endogenous determinants of ICWs. We also note that when we run a test of a comparison of 
coefficients, $\mathrm{a}_{2}=\mathrm{a}_{2}+\mathrm{a}_{3}$, the null of equality is rejected at the .01 level of significance (F-stats of 6.32 and 4.01 for Models 1A and 1B, respectively).

Table 4 contains our results from estimating Models 2A and 2B. In Panel A, we examine the impact of Section 302 ICWs on the relationship between $\mathrm{CASH}_{\mathrm{t}}$ and Amihud Illiquidity. We do not find coefficient $a_{4}$ to be significant in either Model 2A or 2B, suggesting that management-reported Section 302 ICWs do not significantly impact the relationship between $\mathrm{CASH}_{\mathrm{t}}$ and Amihud Illiquidity. In Panel B, we display the results of our analysis of Section 404 weaknesses on the relationship between $\mathrm{CASH}_{\mathrm{t}}$ and Illiquidity. We find coefficient $a_{4}$ to be positive and significant in both Models 2A and 2B. We note that an F-test rejects the null of equality of coefficients, $\mathrm{a}_{2}=\mathrm{a}_{2}+\mathrm{a}_{4}$, at the 0.01 level (F-stats of 15.37 and 12.73 for Models 2A and 2B, respectively). Our results imply that for firms that report auditor-generated Section $404 \mathrm{ICWs}$, the relationship between $\mathrm{CASH}_{\mathrm{t}}$ and Illiquidity is less negative, i.e. the impact of $\mathrm{CASH}_{t}$ on Liquidity is less positive. Based on our conjecture that Section 404 ICWs increase the uncertainty regarding a firm's use of cash, our findings are consistent with those of Gopalan, Kadan and Pevzner (2012), who find that greater uncertainty over future uses of cash may prompt outside providers of capital to discount the importance of such cash holdings in their determination of firms' liquidity.

\section{Conclusion}

In this paper, we examine how Internal Control Weaknesses (either Section 302 or Section 404) reported by firms or by their auditors impact firms' cash-to-cash flow sensitivities and the association between cash holdings of those firms and their stock liquidity. We find that Section 404 Internal Control Weaknesses increase firms cash-to-cash flow sensitivities and reduce the positive impact of cash holdings on firms' stock liquidity. Thus, our paper provides evidence that the presence of Internal Control Weaknesses can increase firms' financing constraints and cause greater reliance on internally generated cash flow to fund their operations. Moreover, we show that these weaknesses reduce the positive impact of internal cash holdings on the liquidity of these firms' stocks. In other words, ICWs may not only force firms to rely more on internal cash financing, but may also attenuate the positive effect of cash holdings on stock liquidity. Thus, our paper describes additional channels through which poor internal controls impose costs on managers and their firms. Broadly speaking, this increased 
reliance on internal financing in the presence of ICWs may produce macro-economic effects through cash hoarding and lower overall investment within the economy. As the PCAOB maintains its strong emphasis on the importance of internal control audits, our study contributes to the understanding of the effect that these audits have on the capital markets and firms' financing policies. Our results contribute to the broad, ongoing public policy debate about the impact of the Sarbanes-Oxley Act on capital formation in the United States, a discussion relevant to stakeholders both inside and outside the firm. 


\section{Appendix: Variable Definitions}

$\Delta \mathrm{CASH}_{\mathrm{t}} \quad$ The change in cash $\left(\Delta \mathrm{Cash}_{\mathrm{t}} /\right.$ Assets $\left._{\mathrm{t}-1}\right)$

WEAK Indicator variable equal to 1 if Audit Analytics reports Section302 (or Section 404) ICW any

$(302 / 404) \quad$ of the years $\mathrm{t}, \mathrm{t}-1$, or $\mathrm{t}-2$

CFO (Operating Cash Flow ( $\left._{\mathrm{t}}\right) /$ Assets $_{\mathrm{t}-1}$

LMVE $\quad$ Log (Market Value of Equity)

LAGE Log (firm age).

TOBIN (Tobin's Q) $)_{\mathrm{t}}$; defined as (Market Value of Equity + Liabilities) / (Book Value of Equity + Liabilities)

ILLIQ (Amihud Illiquidity) $\mathrm{t}$; defined as annual average of daily ratio of absolute value of daily CRSP stock returns to dollar volume: $\mid$ Ret $_{\mathrm{t}} \mid /\left({\text { dollar volume })_{\mathrm{t}}}_{\mathrm{t}}\right.$

INVEST $\quad$ (Capital Expenditures + Research \& Development Costs) $)_{\mathrm{t}} /$ Assets $_{\mathrm{t}-1}$

MTB Market-to-book ratio

STDRET Standard deviation of daily CRSP stock returns

LEV Total Liabilities/ Total Assets

LOSS Indicator variable equal to 1 if $\mathrm{ROA}<0$; equal to 0 otherwise.

LSEGM Natural log of the number of segments (Compustat).

FOREIGN Indicator variable equal to 1 if a firm reports income from foreign operations; equal to 0 otherwise.

MA Indicator variable equal to 1 if Compustat reports a merger or acquisition during the year; equal to 0 otherwise.

RESTRUCTURE Indicator variable equal to 1 if Compustat reports any restructuring charges during the year; equal to 0 otherwise.

$\triangle E A R N \quad$ Annual change in firms' earnings, deflated by prior period total assets

$\triangle$ ALTMAN Percentage change in a firm's Altman Z-Score

B5 Indicator variable equal to 1 if a firm is a Big $\mathrm{N}$ firm; equal to 0 otherwise. 
CASH Firm's Cash (CHE) deflated by prior period assets

$\triangle \mathrm{SALE} \quad$ Annual change in firms sales deflated by prior period assets

INVT $\quad$ Inventory $_{\mathrm{t}} /$ Assets $_{\mathrm{t}-1}$

AR (Accounts Receivable $\left.{ }_{t}\right) /$ Assets $_{\mathrm{t}-1}$

RESTATE Indicator variable equal to 1 if a firm had a restatement indicated in Audit Analytics; equal to 0 otherwise. 


\section{References:}

Almeida, H. M. Compello, and M. Weisbach (2004). The cash flow sensitivity of cash. Journal of Finance, 59(4), 17771804

Amihud, Y. (2002). Illiquidity and stock returns: cross-section and time-series effects. Journal of Financial and Quantitative Analysis, 5(1), 31-56

Amihud, Y. and H. Mendelson (1986). Asset pricing and the bid-ask spread. Journal of Financial Economics, 17(2), 223-249

Ashbaugh-Skaife, H., D. Collins, and W. Kinney (2007). The discovery and reporting of internal control deficiencies prior to SOX-Mandated Audits. Journal of Accounting and Economics, 44, 166-192

Ashbaugh-Skaife, H., D. Collins, W. Kinney, and R. LaFond (2009). The effect of SOX internal control deficiencies on firm risk and cost of equity. Journal of Accounting Research, 47(1), 1-43

Ashbaugh-Skaife, H., D. Veenman, and D. Wangerin (2013). Internal control over financial reporting and managerial rent extraction: Evidence from the profitability of insider trading. Journal of Accounting and Economics, 55, 91-110

Beck, T., A. Demirgüç-Kunt, L. Laeven, and V. Maksimovic (2006). The determinants of financing obstacles. Journal of International Money and Finance, 25(6), 932-952

Beneish, M., M. Billings, and L. Hodder (2008). Internal control weaknesses and information uncertainty. The Accounting Review, 83(3), 665-703

Castello, A. and R. Wittenberg-Moerman (2011). The impact of financial reporting quality on debt contracting: evidence from internal control weaknesses reports. Journal of Accounting Research, 49(1), 97-136

Chan, K. C., B. Farrell, and P. Lee (2008). Earnings management of firms reporting material internal control weaknesses under Section 404 of the Sarbanes-Oxley Act. Auditing: A Journal of Practice \& Theory, 27(2), 161-179.

Charoenwong, C., B. Chong, and Y.Yang (2014). Asset Liquidity and Stock Liquidity: International Evidence. Journal of Business, Finance, and Accounting, 41(3), 432-468

Cheng, M., D. Dhaliwal, and Y. Zhang (2013). Does investment efficiency improve after the disclosure of material weaknesses in internal control over financial reporting? Journal of Accounting and Economics, forthcoming.

Dhaliwal, D., C. Hogan, R. Trezevant, and M. Wilkins (2011). Internal control disclosures, monitoring and cost of debt. The Accounting Review, 86(4), 1131-1156

Doyle, J., W. Ge and S. McVay (2007a). Determinants of weaknesses in internal control over financial reporting. Journal of Accounting and Economics, 44, 193-223

Doyle, J., W. Ge and S. McVay (2007b). Accruals quality and internal control over financial reporting. The Accounting Review, 82(5), 1141-1170

Feng, M., C. Li, and S. McVay (2009). Internal controls and management guidance. Journal of Accounting and Economics, 48, 190-209

Feng, M., C. Li, S. McVay and H. Ashbaugh-Skaife Ineffective Internal Control over Financial Reporting and Firm Operations (2012). Working Paper, available on SSRN at: http://papers.ssrn.com/sol3/papers.cfm?abstract id=2187599 
Ge, W. and S. McVay (2005). The disclosure of material weaknesses in internal control after Sarbanes-Oxley Act. The Accounting Horizons, 19(3), 137-158

Ghosh, A. and Y. Lee (2013). Financial reporting quality, structural problems, and the informativeness of mandated disclosures on internal controls. Journal of Business, Finance and Accounting, 40(3), 318-349

Gopalan, R., O. Kadan, and M. Pevzner (2012). Asset liquidity and stock liquidity. Journal of Financial and Quantitative Analysis, 47(2), 333-364

Hammersley, J., L. Myers and K. Shakespeare (2008). Market reactions to the disclosure of internal control weaknesses and to the characteristics of those weaknesses under Section 302 of Sarbanes Oxley Act of 2002. Review of Accounting Studies, 13, 141-165

Hoitash, R., Hoitash, U. and J. Bedard (2008). Internal control quality and audit pricing under the Sarbanes-Oxley Act, Auditing: Journal of Practice and Theory, 27(1), 105-126

Hoitash, R., Hoitash, U. and K. Johnstone (2012). Internal control material weaknesses and CFO Compensation. Contemporary Accounting Research, 29(3), 768-803

Johnstone, K., C. Li, and K. Rupley (2011). Changes in corporate governance associated with internal control material weaknesses and their subsequent remediation. Contemporary Accounting Research, 28(1), 331-383

Khurana, I., X. Martin, and R. Pereira (2006). Financial development and the cash flow sensitivity of cash. Journal of Financial and Quantitative Analysis, 41(4), 787-807

Kim, J., B. Song, and L. Zhang (2011). Internal control weaknesses and bank loan contracting: Evidence from SOX Section 404 disclosures. The Accounting Review, 86(4), 1157-1188

Kim, Y. and M. Park (2009). Market uncertainty and disclosure of internal control deficiencies under the SarbanesOxley Act. Journal of Accounting and Public Policy, 28(5), 419-445

Lahart, J. (2010). Companies cling to cash. Wall Street Journal, December 10, 2010. Available on-line at: http://online.wsj.com/news/articles/SB10001424052748703766704576009501161973480?mod=WSJ_hp_LEFTWhatsN ewsCollection\&mg=reno64-wsj

Lin, Y. (2007). The cash flow sensitivity of cash: evidence from Taiwan. Applied Financial Economics, 17(2), 10131024

Lopez, T., S. Vandervelde, and Y. Wu (2009). Investor perceptions of an auditor's adverse internal control opinion. Journal of Accounting and Public Policy, 28(3), 231-250

Ogneva, M., K.R. Subramanyam, and K. Raghunandan (2007). Internal control weaknesses and Cost of Equity: Evidence from SOX 404 Audits. The Accounting Review, 82(5), 1255-1297

Petersen, M. (2009). Estimating standard errors in finance panel data sets: comparing approaches. Review of Financial Studies, 22(1): 435-480

Raghunandan, K. and D. Rama (2006). SOX 404 material weakness disclosures and audit fees. Auditing: Journal of Practice and Theory, 25(1), 99-114

Schneider, A. and B. Church (2008). The effect of auditors' internal control opinions on loan decisions. Journal of Accounting and Public Policy, 27(1), 1-18 
Tang, D., F. Tian, and H. Yan (2012). Creditors' expected recovery and internal control quality: evidence from credit default swaps. Working Paper. The University of Hong Kong.

Table 1

\section{Descriptive Statistics}

Table reports the descriptive statistics for 10,214 observations in our sample. All variables are defined in the Appendix. Panel A: Summary Statistics

\begin{tabular}{|c|c|c|c|c|c|}
\hline VARIABLE & MEAN & STD & Q1 & MEDIAN & Q3 \\
\hline WEAK (302) & .23 & .42 & 0 & 0 & 0 \\
\hline WEAK (404) & .12 & .32 & 0 & 0 & 0 \\
\hline ILLIQ $_{\mathbf{t}}$ & 1.38 & 6.30 & .00 & .01 & .15 \\
\hline $\mathrm{CFO}_{\mathrm{t}}$ & .04 & .22 & -.00 & .08 & .15 \\
\hline $\mathrm{CASH}_{\mathrm{t}}$ & .28 & .31 & .06 & .17 & .41 \\
\hline$\Delta \mathrm{CASH}_{\mathrm{t}}$ & .02 & .19 & -.04 & .00 & .06 \\
\hline LMVE $_{t}$ & 5.95 & 1.97 & 4.57 & 5.91 & 7.23 \\
\hline INVEST $_{t}$ & .14 & .15 & .04 & .09 & .18 \\
\hline MTB $_{t}$ & 2.75 & 4.86 & 1.15 & 1.98 & 3.47 \\
\hline STDRET $_{t}$ & .04 & .02 & .02 & .03 & .05 \\
\hline LSEGM $_{t}$ & 1.69 & .58 & 1.39 & 1.39 & 2.30 \\
\hline FOREIGN & .43 & .50 & 0 & 0 & 1 \\
\hline MA & .89 & .31 & 1 & 1 & 1 \\
\hline RESTRUCTURE & .28 & .45 & 0 & 0 & 1 \\
\hline$\Delta \mathbf{S A L E}_{\mathrm{t}}$ & .09 & .26 & -.02 & .06 & .19 \\
\hline INVT $_{t}$ & .10 & .14 & .00 & .05 & .16 \\
\hline $\mathbf{A} \mathbf{R}_{\mathbf{t}}$ & .15 & .13 & .05 & .12 & .21 \\
\hline $\mathbf{L O S S}_{t}$ & .40 & .49 & 0 & 0 & 1 \\
\hline$\Delta \mathbf{E A R N}_{\mathrm{t}}$ & .01 & .18 & -.04 & .01 & .05 \\
\hline$\Delta$ ALTMAN $_{\mathbf{t}}$ & -.00 & 1.28 & -.31 & -.04 & .19 \\
\hline
\end{tabular}




\begin{tabular}{cccccc}
\hline LAGE $_{\mathbf{t}}$ & 8.10 & .71 & 7.80 & 8.26 & 8.57 \\
B5 & .75 & .43 & 1 & 1 & 1 \\
\hline RESTATE & .08 & .28 & 0 & 0 & 0 \\
\hline LEV & .48 & .28 & .27 & .45 & .63 \\
\hline
\end{tabular}


Table 1

Descriptive Statistics

Table reports the descriptive statistics for 10,214 firm year observations in our sample. All variables are defined in the Appendix.

Panel B: Annual sample distribution

\begin{tabular}{|c|c|c|c|}
\hline Year & Obs. & $\begin{array}{l}\% \text { of } \\
\text { Total }\end{array}$ & $\begin{array}{c}\text { Cumulative \% } \\
\text { of Total }\end{array}$ \\
\hline 2005 & 1,855 & $18 \%$ & $18 \%$ \\
\hline 2006 & 1,795 & $18 \%$ & $36 \%$ \\
\hline 2007 & 1,774 & $17 \%$ & $53 \%$ \\
\hline 2008 & 1,696 & $17 \%$ & $70 \%$ \\
\hline 2009 & 1,595 & $16 \%$ & $85 \%$ \\
\hline 2010 & 1,499 & $15 \%$ & $100 \%$ \\
\hline Total & 10,214 & $100 \%$ & $100 \%$ \\
\hline
\end{tabular}

Panel C: Industry Distribution

\begin{tabular}{rrrrr}
$\begin{array}{r}\text { Two Digit } \\
\text { SIC Code }\end{array}$ & Obs. & $\begin{array}{r}\text { \% of } \\
\text { Total }\end{array}$ & $\begin{array}{l}\text { Cum. \% } \\
\text { of Total }\end{array}$ \\
\hline & & & & \\
\hline $\mathbf{1 - 1 0}$ & 127 & $1.24 \%$ & $1.24 \%$ \\
\hline $\mathbf{1 1 - 2 0}$ & 591 & $5.79 \%$ & $7.03 \%$ \\
\hline $\mathbf{2 1 - 3 0}$ & 1,871 & $18.32 \%$ & $25.35 \%$ \\
\hline $\mathbf{3 1 - 4 0}$ & 3,195 & $31.28 \%$ & $56.63 \%$ \\
\hline $\mathbf{4 1 - 5 0}$ & 1,215 & $11.90 \%$ & $68.52 \%$ \\
\hline $\mathbf{5 1 - 6 0}$ & 844 & $8.26 \%$ & $76.79 \%$ \\
\hline $\mathbf{6 1 - 7 0}$ & 41 & $.40 \%$ & $77.19 \%$ \\
\hline $\mathbf{7 1 - 8 0}$ & 1,951 & $19.10 \%$ & $96.29 \%$ \\
\hline $\mathbf{8 1 - 9 0}$ & 363 & $3.55 \%$ & $99.84 \%$ \\
\hline $\mathbf{9 1 - 9 9}$ & 16 & $.16 \%$ & $100 \%$ \\
\hline Total & $\mathbf{1 0 , 2 1 4}$ & $\mathbf{1 0 0 \%}$ & \\
\hline
\end{tabular}


Variable Descriptions: $\boldsymbol{A C A S H}=$ The change in cash $(\triangle \mathrm{Cash} /$ Assets $)$; WEAK (302/404) $=1$ if Audit Analytics reports Section302 (or Section 404) ICW any of the years t, t-1, or t-2, = 0 otherwise; $\boldsymbol{C F O}=($ Operating Cash Flow)/Assets; $\boldsymbol{L M V E}$ $=\log$ (Market Value of Equity); $\boldsymbol{L A G E}=\log ($ firm age $) ; \boldsymbol{T O B I N}=($ Tobin's Q), defined as (Market Value of Equity + Liabilities) / (Book Value of Equity + Liabilities); ILLIQ = (Amihud Illiquidity), defined as annual average of daily ratio of absolute value of daily CRSP stock returns to dollar volume: $\mid$ Ret $/($ dollar volume $) ; \boldsymbol{I N V E S T}=($ Capital Expenditures + Research \& Development Costs) / Assets; MTB = Market-to-book ratio; STDRET = Standard deviation of daily CRSP stock returns; $\boldsymbol{L E} \boldsymbol{V}=$ Total Liabilities/ Total Assets; $\boldsymbol{L O S S}=1$ if ROA $<0,=0$ otherwise; $\boldsymbol{L S E \boldsymbol { G }}=$ Natural log of the number of segments (Compustat); FOREIGN $=1$ if a firm reports income from foreign operations, $=0$ otherwise; $\boldsymbol{M A}=1$

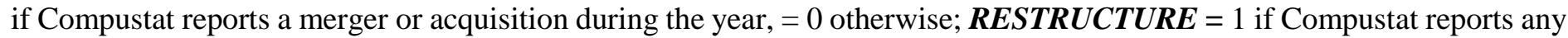

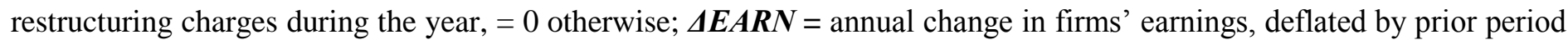
total assets; $\triangle \boldsymbol{A L T M A N}=$ Percentage change in a firm's Altman Z-Score; $\boldsymbol{B 5}=1$ if a firm is a Big N firm,= 0 otherwise; $\boldsymbol{C A S H}=$ Firm's Cash balance (CHE) deflated by prior period assets; $\boldsymbol{\Delta S \boldsymbol { A } \boldsymbol { E }}=$ Annual change in firms sales deflated by prior period assets; $\boldsymbol{I N V \boldsymbol { T }}=$ Inventory $/$ Assets; $\boldsymbol{A R}=($ Accounts Receivable) $/$ Assets; $\boldsymbol{R E S T A T E}=1$ if a firm had a restatement indicated in Audit Analytics, $=0$ otherwise. 
Table 2

\section{Pearson Correlations}

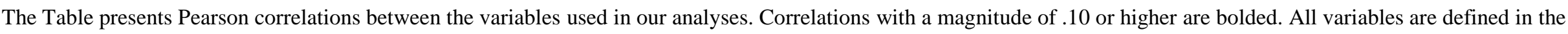
Appendix.

\begin{tabular}{|c|c|c|c|c|c|c|c|c|c|c|c|c|c|c|c|c|c|c|c|c|c|c|c|c|c|}
\hline & & 1 & 2 & 3 & 4 & 5 & 6 & 7 & 8 & 9 & 10 & 11 & 12 & 13 & 14 & 15 & 16 & 17 & 18 & 19 & 20 & 21 & 22 & 23 & 24 \\
\hline 1 & WEAK (302) & & & & & & & & & & & & & & & & & & & & & & & & \\
\hline 2 & WEAK (404) & .65 & & & & & & & & & & & & & & & & & & & & & & & \\
\hline 3 & ILLIQ $_{t}$ & .04 & $\begin{array}{r}- \\
.06\end{array}$ & & & & & & & & & & & & & & & & & & & & & & \\
\hline 4 & $\mathrm{CFO}_{\mathrm{t}}$ &. & .01 & .12 & & & & & & & & & & & & & & & & & & & & & \\
\hline 5 & CASH &. & $\begin{array}{r}- \\
.03\end{array}$ & - & .26 & & & & & & & & & & & & & & & & & & & & \\
\hline 6 & $\Delta \mathrm{CASH}_{\mathrm{t}}$ &. & .00 & - & .13 & .58 & & & & & & & & & & & & & & & & & & & \\
\hline 7 & LMVE $_{t}$ &. & $\begin{array}{r}- \\
.01\end{array}$ & .35 & .41 & $\begin{array}{r}- \\
.04\end{array}$ & .13 & & & & & & & & & & & & & & & & & & \\
\hline 8 & INVEST $_{\mathrm{t}}$ & $\begin{array}{r}- \\
.04\end{array}$ & .04 & .04 &.$\overline{-}$ & .46 & .14 & $\begin{array}{r}- \\
.06\end{array}$ & & & & & & & & & & & & & & & & & \\
\hline 9 & $\mathrm{MTB}_{\mathrm{t}}$ & $\begin{array}{r}- \\
.05\end{array}$ & $\begin{array}{r}- \\
.03\end{array}$ & $\begin{array}{r}- \\
.05\end{array}$ & $\begin{array}{r}- \\
.01\end{array}$ & .18 & .10 & .15 & .12 & & & & & & & & & & & & & & & & \\
\hline 10 & STDRET $_{\mathrm{t}}$ & .11 & .01 & .41 &. & .05 & .04 &. & .15 & - & & & & & & & & & & & & & & & \\
\hline 11 & LSEGM $_{\mathrm{t}}$ & $\begin{array}{r}- \\
.00\end{array}$ & .03 & - & .19 & .23 & $\begin{array}{r}- \\
.08\end{array}$ & .28 & .22 &. & . & & & & & & & & & & & & & & \\
\hline 12 & FOREIGN & .03 & .05 & .05 & .14 & .01 & .00 & .19 &. &. &. & .11 & & & & & & & & & & & & & \\
\hline 13 & MA & .01 & .00 & .04 & .08 & .05 & .05 & $\begin{array}{r}- \\
.05\end{array}$ & .04 & .01 & .09 & .04 &. & & & & & & & & & & & & \\
\hline 14 & RESTRUCTURE & .04 & .07 & . & - & $\begin{array}{r}- \\
.09\end{array}$ & $\begin{array}{r}- \\
.07\end{array}$ & .11 & . & - & - & .09 & .25 & . & & & & & & & & & & & \\
\hline 15 & $\Delta$ Sale $_{\mathrm{t}}$ & $\begin{array}{r}- \\
.03\end{array}$ & $\begin{array}{r}- \\
.03\end{array}$ & . & .15 & .07 & .13 & .14 & .08 & .10 & $\begin{array}{r}- \\
.15\end{array}$ & .01 & $\begin{array}{r}- \\
.03\end{array}$ & .19 & . & & & & & & & & & & \\
\hline 16 & $\mathrm{INVT}_{\mathrm{t}}$ & .03 &. & .05 & .04 & .23 & .01 & .08 & 19 & .06 & .02 & .05 & .05 & .01 & .02 & .17 & & & & & & & & & \\
\hline 17 & $\mathrm{AR}_{\mathrm{t}}$ & .04 & .01 & .02 & .16 & .12 & .09 & - & 19 & .01 &. & .09 & .12 & .14 & .01 & .33 & .22 & & & & & & & & \\
\hline 18 & LOSS $_{\mathrm{t}}$ & .12 & .07 & .17 & . & .16 & .12 & .46 & .26 & .04 & .43 & . &. & .06 & .07 & .25 & .14 & .21 & & & & & & & \\
\hline 19 & $\Delta \mathrm{EARN}_{\mathrm{t}}$ & - & - & .05 & .10 & .04 & .06 & .01 & .03 & .05 & .04 & - & .00 & .05 & .00 & .14 & .01 & .08 & . & & & & & & \\
\hline 20 & $\triangle$ ALTMAN $_{\mathrm{t}}$ &. & .02 & .01 & .01 & .02 & .04 & .04 &. & .01 & .00 & - & .02 & .05 & .02 & .01 & .02 & $\begin{array}{r}- \\
.03\end{array}$ & .05 & .08 & & & & & \\
\hline 21 & $\mathrm{LAGE}_{\mathrm{t}}$ & .00 & .03 & .01 & .08 & - & $\begin{array}{r}- \\
.01\end{array}$ & .08 & . & - & - & .15 & .11 & .04 & .11 &. & .11 & .07 & $\begin{array}{r}- \\
.08\end{array}$ & .02 & .01 & & & & \\
\hline
\end{tabular}




\begin{tabular}{|c|c|c|c|c|c|c|c|c|c|c|c|c|c|c|c|c|c|c|c|c|c|c|c|c|}
\hline 22 & B5 & ${ }^{-}$ & $\begin{array}{r}- \\
.04\end{array}$ & $2 \overline{2}$ & .16 & $\begin{array}{r}- \\
.01\end{array}$ & .00 & .46 & .02 & .03 & 25 & .10 & .12 & $\begin{array}{r}- \\
.00\end{array}$ & .15 & .01 & $\begin{array}{r}- \\
.07\end{array}$ & .12 & $\begin{array}{r}- \\
.16\end{array}$ & .02 & .01 & $\begin{array}{r}- \\
.06\end{array}$ & & \\
\hline 23 & RESTATE & .29 & .23 & $\begin{array}{r}- \\
01\end{array}$ & - & .04 & .00 & $\begin{array}{r}- \\
\end{array}$ & .04 & $\begin{array}{r}- \\
.01\end{array}$ & .00 & .00 & .00 & .00 & .03 & .01 & .03 & .01 & .04 & .01 & $\begin{array}{r}- \\
.01\end{array}$ & .00 & .04 & \\
\hline 24 & LEV & .05 & .03 & .03 & .07 & .29 & 10 & .00 & .00 & 10 & .16 & .04 & .05 & .01 & .13 &. & .02 & .01 & .13 &. & .01 & .03 & .08 & .04 \\
\hline
\end{tabular}

Variable Descriptions: $\boldsymbol{A C A S H}=$ The change in cash $(\triangle \mathrm{Cash} /$ Assets); $\boldsymbol{W E A K}(\mathbf{3 0 2 / 4 0 4 )}=1$ if Audit Analytics reports Section302 (or Section 404$)$ ICW any of the years t, t-1, or t-2, $=0$ otherwise; $\boldsymbol{C F O}=($ Operating Cash Flow $) /$ Assets; $\boldsymbol{L M V E}=\log$ (Market Value of Equity); $\boldsymbol{L A G E}=\log ($ firm age $) ; \boldsymbol{T O B I N}=($ Tobin's Q), defined as (Market Value of Equity + Liabilities) / (Book Value of Equity + Liabilities); ILLIQ = (Amihud Illiquidity), defined as annual average of daily ratio of absolute value of daily CRSP stock returns to dollar volume: $\mid$ Ret $\mid /($ dollar volume); INVEST = (Capital Expenditures + Research \& Development Costs) / Assets; $\boldsymbol{M T B}=$ Market-to-book ratio; $\boldsymbol{S T D R E T}=$ Standard deviation of daily CRSP stock returns; $\boldsymbol{L E V}=$ Total Liabilities/ Total Assets; $\boldsymbol{L O S S}=1$ if ROA $<0,=0$ otherwise; $\boldsymbol{L S E G M}=$ Natural $\log$ of the number of segments (Compustat); $\boldsymbol{F O R E I G N}=1$ if a firm reports income from foreign operations, = 0 otherwise; $\boldsymbol{M A}=1$ if Compustat reports a merger or acquisition during the year, $=0$ otherwise; RESTRUCTURE $=1$ if Compustat reports any restructuring charges during the year, = 0 otherwise; $\boldsymbol{A} \boldsymbol{E} \boldsymbol{A} \boldsymbol{R} \boldsymbol{N}=$ annual change in firms' earnings, deflated by prior period total assets; $\triangle \boldsymbol{A} \boldsymbol{L} \boldsymbol{T} \boldsymbol{M} \boldsymbol{A} \boldsymbol{N}=$ Percentage change in a firm's Altman Z-Score; $\boldsymbol{B} 5=1$ if a firm is a Big N firm, $=0$ otherwise; $\boldsymbol{C A S H}=$ Firm's Cash balance (CHE) deflated by prior period assets; $\Delta \boldsymbol{S A L E}=$ Annual change in firms sales deflated by prior period assets; $\boldsymbol{I N V T}=$ Inventory $/$ Assets; $\boldsymbol{A R}=($ Accounts Receivable $) /$ Assets; $\boldsymbol{R E S T A T E}=1$ if a firm had a restatement indicated in Audit Analytics, $=0$ otherwise. 
Table 3

The impact of Internal Control Weaknesses on Firms' Cash Flows Sensitivities of Cash

The Table summarizes estimations of models (1A) and (1B) in the paper. Each model presented reports t-statistics estimated using standard errors clustered on firm level, and includes year and industry fixed effects per Petersen (2009). All continuous variables are winsorized at the $1^{\text {st }}$ and $99^{\text {th }}$ percentiles, * denotes two-tail significance levels of .05 . All variables are defined in the Appendix.

Panel A: Impact of Section 302 Internal Control Weaknesses

\begin{tabular}{|c|c|c|c|c|c|}
\hline$D E P V A R=\Delta C A S H_{t}$ & & \multicolumn{2}{|c|}{ Model 1A } & \multicolumn{2}{|c|}{ Model 1B } \\
\hline Variables & Coef. & $\begin{array}{l}\text { Coefficient } \\
\text { Estimate }\end{array}$ & t-stat & $\begin{array}{c}\text { Coefficient } \\
\text { Estimate }\end{array}$ & t-stat \\
\hline WEAK (302) & $a_{1}$ & .00 & $(.36)$ & .00 & $(.87)$ \\
\hline $\mathrm{CFO}_{\mathrm{t}}$ & $a_{2}$ & .25 & $(1.41)$ & $.63 *$ & $(2.81)$ \\
\hline CFO $_{\mathrm{t}} * \operatorname{WEAK}(302)$ & $a_{3}$ & .06 & $(1.33)$ & .02 & (.39) \\
\hline $\mathbf{L M V E}_{t-1}$ & $a_{4}$ & $-.01 *$ & $(-5.06)$ & -.00 & $(-1.79)$ \\
\hline $\mathrm{CFO}_{\mathrm{t}}^{*}{ }^{*} \mathrm{LMVE}_{\mathrm{t}-1}$ & $a_{5}$ & $.02 *$ & $(1.89)$ & .00 & (.37) \\
\hline $\mathbf{L A G E}_{t}$ & $a_{6}$ & -.00 & $(-.34)$ & .00 & $(1.45)$ \\
\hline $\mathrm{CFO}_{\mathrm{t}} * \mathrm{LAGE}_{\mathrm{t}}$ & $a_{7}$ & -.02 & $(-1.02)$ & $-.05 *$ & $(-2.23)$ \\
\hline TOBIN $_{t}$ & $\mathrm{a}_{8}$ & $.02 *$ & $(8.68)$ & $.01 *$ & $(5.01)$ \\
\hline LSEGM $_{t}$ & a9 & & & .01 & $(1.83)$ \\
\hline CFO $_{t} *$ LSEGM $_{t}$ & $a_{10}$ & & & -.06 & $(-1.59)$ \\
\hline$\Delta \mathbf{S A L E}_{\mathbf{t}}$ & $a_{11}$ & & & $.05^{*}$ & $(5.73)$ \\
\hline CFO $^{*}{ }^{*} \Delta$ SALE $_{t}$ & $a_{12}$ & & & .10 & $(1.33)$ \\
\hline FOREIGN $_{t}$ & $a_{13}$ & & & -.01 & $(-1.11)$ \\
\hline CFO $_{t} *$ FOREIGN ${ }_{t}$ & $\mathrm{a}_{14}$ & & & $.11^{*}$ & $(2.83)$ \\
\hline $\mathbf{M A}_{\mathbf{t}}$ & $a_{15}$ & & & $.05^{*}$ & $(5.74)$ \\
\hline $\mathrm{CFO}_{t} * \mathbf{M A}_{\mathrm{t}}$ & $a_{16}$ & & & -.07 & $(-1.02)$ \\
\hline RESTRUCTURE $_{t}$ & $a_{17}$ & & & -.01 & $(-1.76)$ \\
\hline CFO $_{t}{ }^{*}$ RESTRUCTURE $_{t}$ & $a_{18}$ & & & .08 & (1.76) \\
\hline
\end{tabular}




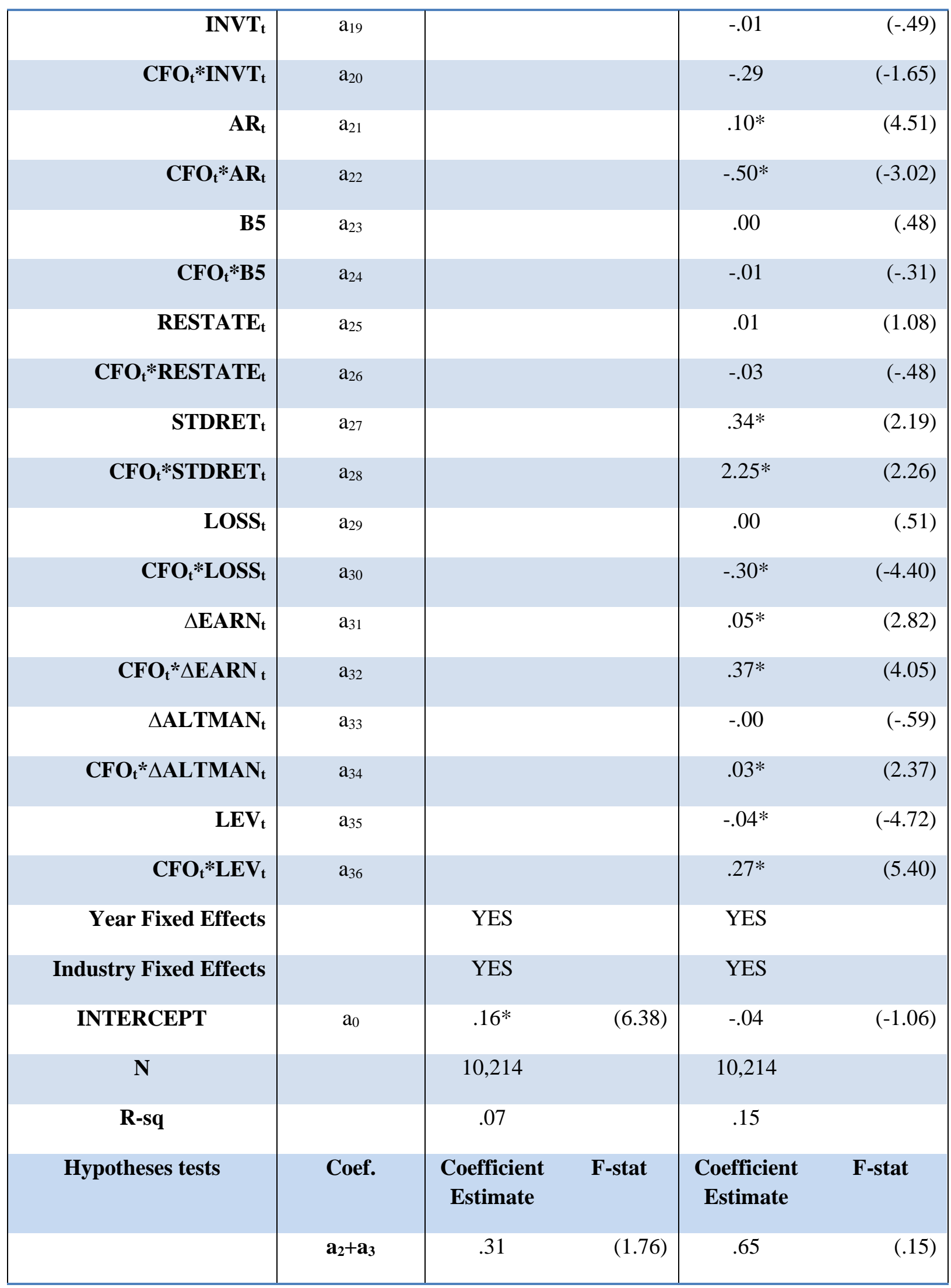


Table 3

The impact of Internal Control Weaknesses on Firms' Cash Flows Sensitivities of Cash

The Table summarizes estimations of models (1A) and (1B) in the paper. Each model presented reports t-statistics estimated using standard errors clustered on firm level, and includes year and industry fixed effects per Petersen (2009). All continuous variables are winsorized at the $1^{\text {st }}$ and $99^{\text {th }}$ percentiles, * denotes two-tail significance levels of .05 . All variables are defined in the Appendix.

Panel B: Impact of Section 404 Internal Control Weaknesses

\begin{tabular}{|c|c|c|c|c|c|}
\hline$D E P V A R=\Delta C A S H_{t}$ & & \multicolumn{2}{|c|}{ Model 1A } & \multicolumn{2}{|c|}{ Model 1B } \\
\hline Variables & Coef. & $\begin{array}{c}\text { Coefficient } \\
\text { Estimate }\end{array}$ & t-stat & $\begin{array}{l}\text { Coefficient } \\
\text { Estimate }\end{array}$ & t-stat \\
\hline WEAK (404) & $a_{1}$ & -.00 & $(-.08)$ & .00 & (.43) \\
\hline $\mathrm{CFO}_{\mathrm{t}}$ & $\mathrm{a}_{2}$ & .29 & $(1.65)$ & $.65^{*}$ & (2.90) \\
\hline CFO $_{t} * \operatorname{WEAK}(404)$ & $a_{3}$ & $.13^{*}$ & $(2.51)$ & $.11 *$ & $(2.00)$ \\
\hline $\mathbf{L M V E}_{t-1}$ & $\mathrm{a}_{4}$ & $-.01 *$ & $(-4.90)$ & -.00 & $(-1.69)$ \\
\hline $\mathrm{CFO}_{\mathrm{t}}{ }^{*} \mathrm{LMVE}_{\mathrm{t}-1}$ & $a_{5}$ & .02 & (1.59) & .00 & $(.27)$ \\
\hline LAGE $_{t}$ & $\mathrm{a}_{6}$ & -.00 & $(-.31)$ & .00 & (1.43) \\
\hline $\mathrm{CFO}_{t}{ }^{*} \mathrm{LAGE}_{\mathrm{t}}$ & $\mathrm{a}_{7}$ & -.03 & $(-1.13)$ & $-.05^{*}$ & $(-2.33)$ \\
\hline TOBIN $_{t}$ & $\mathrm{a}_{8}$ & $.02^{*}$ & (8.66) & $.01^{*}$ & (4.93) \\
\hline LSEGM $_{t}$ & $\mathrm{a}_{9}$ & & & .01 & (1.74) \\
\hline CFO $_{t}{ }^{*}$ LSEGM $_{t}$ & $a_{10}$ & & & -.06 & $(-1.61)$ \\
\hline$\triangle$ SALE $_{\mathbf{t}}$ & $a_{11}$ & & & $.05^{*}$ & (5.75) \\
\hline CFO $_{t} * \Delta$ SALE $_{t}$ & $a_{12}$ & & & .10 & (1.28) \\
\hline FOREIGN $_{t}$ & $a_{13}$ & & & -.01 & $(-1.08)$ \\
\hline CFO $_{t}{ }^{* F O R E I G N} N_{t}$ & $a_{14}$ & & & $.11^{*}$ & (2.74) \\
\hline $\mathbf{M A}_{\mathbf{t}}$ & $a_{15}$ & & & $.05^{*}$ & (5.69) \\
\hline $\mathrm{CFO}_{\mathrm{t}} * \mathrm{MA}_{\mathrm{t}}$ & $\mathrm{a}_{16}$ & & & -.07 & $(-1.01)$ \\
\hline RESTRUCTURE $_{t}$ & $a_{17}$ & & & -.01 & $(-1.68)$ \\
\hline CFO $_{t} *$ RESTRUCTURE $_{t}$ & $\mathrm{a}_{18}$ & & & .07 & $(1.62)$ \\
\hline
\end{tabular}




\begin{tabular}{|c|c|c|c|c|c|}
\hline $\mathbf{I N V T}_{\mathbf{t}}$ & $\mathrm{a}_{19}$ & & & -.01 & $(-.45)$ \\
\hline $\mathrm{CFO}_{\mathrm{t}}{ }^{*} \mathrm{INVT}_{\mathrm{t}}$ & $\mathrm{a}_{20}$ & & & -.29 & $(-1.64)$ \\
\hline $\mathbf{A} \mathbf{R}_{t}$ & $a_{21}$ & & & $.10 *$ & $(4.52)$ \\
\hline $\mathrm{CFO}_{\mathrm{t}}{ }^{*} \mathrm{AR}_{\mathrm{t}}$ & $a_{22}$ & & & $-.49 *$ & $(-2.98)$ \\
\hline B5 & $a_{23}$ & & & .00 & $(.42)$ \\
\hline $\mathrm{CFO}_{\mathrm{t}}^{*} \mathrm{B5}$ & $\mathrm{a}_{24}$ & & & -.01 & $(-.20)$ \\
\hline RESTATE $_{t}$ & $a_{25}$ & & & .01 & $(1.16)$ \\
\hline CFO $_{t} *$ RESTATE $_{t}$ & $a_{26}$ & & & -.05 & $(-.72)$ \\
\hline STDRET $_{t}$ & $a_{27}$ & & & $.34 *$ & $(2.21)$ \\
\hline CFO $_{t} *$ STDRET $_{t}$ & $\mathrm{a}_{28}$ & & & $2.32 *$ & (2.36) \\
\hline $\mathbf{L O S S}_{\mathbf{t}}$ & $a_{29}$ & & & .00 & $(.54)$ \\
\hline $\mathrm{CFO}_{\mathrm{t}} * \mathrm{LOSS}_{\mathrm{t}}$ & $\mathrm{a}_{30}$ & & & $-.30 *$ & $(-4.43)$ \\
\hline$\triangle \mathbf{E A R N}_{\mathbf{t}}$ & $a_{31}$ & & & $.05^{*}$ & $(2.79)$ \\
\hline CFO $_{t}{ }^{*} \Delta$ EARN $_{t}$ & $a_{32}$ & & & $.37 *$ & (4.13) \\
\hline$\triangle$ ALTMAN $_{\mathbf{t}}$ & $\mathrm{a}_{33}$ & & & -.00 & $(-0.56)$ \\
\hline CFO $_{t} * \triangle$ ALTMAN $_{t}$ & $\mathrm{a}_{34}$ & & & $.03 *$ & $(2.42)$ \\
\hline $\mathbf{L E V}_{t}$ & $a_{35}$ & & & $-.04 *$ & $(-4.69)$ \\
\hline $\mathrm{CFO}_{\mathrm{t}} * \mathrm{LEV}_{\mathrm{t}}$ & $\mathrm{a}_{36}$ & & & $.27 *$ & $(5.33)$ \\
\hline Year Fixed Effects & & YES & & YES & \\
\hline Industry Fixed Effects & & YES & & YES & \\
\hline INTERCEPT & $\mathrm{a}_{0}$ & $.16^{*}$ & $(6.45)$ & -.03 & $(-.91)$ \\
\hline $\mathbf{N}$ & & 10,214 & & 10,214 & \\
\hline R-sq & & .07 & & .15 & \\
\hline \multirow[t]{2}{*}{ Hypotheses tests } & Coef. & $\begin{array}{c}\text { Coefficient } \\
\text { Estimate }\end{array}$ & F-stat & $\begin{array}{c}\text { Coefficient } \\
\text { Estimate }\end{array}$ & F-stat \\
\hline & $\mathbf{a}_{2}+\mathbf{a}_{3}$ & $.43 *$ & $(6.32)$ & $.76^{*}$ & $(4.01)$ \\
\hline
\end{tabular}


Variable Descriptions: $\boldsymbol{A C A S H}=$ The change in cash $(\triangle \mathrm{Cash} /$ Assets); $\boldsymbol{W E A K}(\mathbf{3 0 2 / 4 0 4})=1$ if Audit Analytics reports Section302 (or Section 404) ICW any of the years t, t-1, or t-2, = 0 otherwise; $\boldsymbol{C F O}=($ Operating Cash Flow)/Assets; $\boldsymbol{L M V E}$ $=\log$ (Market Value of Equity); $\boldsymbol{L A G E}=\log ($ firm age $) ; \boldsymbol{T O B I N}=($ Tobin's Q), defined as (Market Value of Equity + Liabilities) / (Book Value of Equity + Liabilities); ILLIQ = (Amihud Illiquidity), defined as annual average of daily ratio of absolute value of daily CRSP stock returns to dollar volume: $\mid$ Ret $/($ dollar volume $) ;$ INVEST = (Capital Expenditures + Research \& Development Costs) / Assets; MTB = Market-to-book ratio; STDRET = Standard deviation of daily CRSP stock returns; $\boldsymbol{L E} \boldsymbol{V}=$ Total Liabilities/ Total Assets; $\boldsymbol{L O S S}=1$ if ROA $<0,=0$ otherwise; $\boldsymbol{L S E G M}=$ Natural log of the number of segments (Compustat); FOREIGN $=1$ if a firm reports income from foreign operations, $=0$ otherwise; $\boldsymbol{M A}=1$

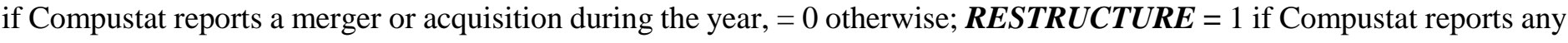
restructuring charges during the year, $=0$ otherwise; $\boldsymbol{\Delta E} \boldsymbol{A} \boldsymbol{R} \boldsymbol{N}=$ annual change in firms' earnings, deflated by prior period total assets; $\triangle \boldsymbol{A L T M A N}=$ Percentage change in a firm's Altman Z-Score; $\boldsymbol{B 5}=1$ if a firm is a Big $\mathrm{N}$ firm, $=0$ otherwise; $\boldsymbol{C A S H}=$ Firm's Cash balance $(\mathrm{CHE})$ deflated by prior period assets; $\triangle \boldsymbol{S A} \boldsymbol{L} \boldsymbol{E}=$ Annual change in firms sales deflated by prior period assets; $\boldsymbol{I N V T}=$ Inventory / Assets; $\boldsymbol{A} \boldsymbol{R}=$ (Accounts Receivable) $/$ Assets; $\boldsymbol{R E S T A T E}=1$ if a firm had a restatement indicated in Audit Analytics, $=0$ otherwise. 
Table 4

The impact of Internal Control Weaknesses on Firms' Relation between Cash and Amihud Illiquidity

The Table summarizes estimations of models (2A) and (2B) in the paper. Each model presented reports t-statistics estimated using standard errors clustered on firm level, and includes year and industry fixed effects per Petersen (2009). All continuous variables are winsorized at the $1^{\text {st }}$ and $99^{\text {th }}$ percentiles, * denotes two-tail significance levels of .05 . All variables are defined in the Appendix.

Panel A: Impact of Section 302 Internal Control Weaknesses

\begin{tabular}{|c|c|c|c|c|c|}
\hline$D E P V A R=I L L I Q_{t}$ & & \multicolumn{2}{|c|}{ Model 2A } & \multicolumn{2}{|c|}{ Model 2B } \\
\hline Variables & Coef. & $\begin{array}{l}\text { Coefficient } \\
\text { Estimate }\end{array}$ & t-stat & $\begin{array}{c}\text { Coefficient } \\
\text { Estimate }\end{array}$ & t-stat \\
\hline ILLIQ $_{\mathrm{t}-1}$ & $a_{1}$ & $.86^{*}$ & $(15.56)$ & $.85^{*}$ & (15.56) \\
\hline $\mathrm{CASH}_{t}$ & $a_{2}$ & $-4.92 *$ & $(-4.07)$ & -3.49 & $(-1.68)$ \\
\hline WEAK(302) & $a_{3}$ & -.04 & $(-.28)$ & -.10 & $(-.60)$ \\
\hline CASH $_{t} *$ WEAK & $\mathrm{a}_{4}$ & -.12 & $(-.30)$ & -.16 & $(-.35)$ \\
\hline LMVE $_{t-1}$ & $a_{5}$ & $-.81 *$ & $(-11.47)$ & $-.60^{*}$ & $(-8.12)$ \\
\hline CASH $_{t} *$ LMVE $_{t-1}$ & $\mathrm{a}_{6}$ & $.70 *$ & $(4.77)$ & $.50 *$ & (3.27) \\
\hline CASH $_{t} *$ INVEST $_{t}$ & $\mathrm{a}_{7}$ & $1.56^{*}$ & (2.40) & $1.65^{*}$ & (2.14) \\
\hline INVEST $_{t}$ & $\mathrm{a}_{8}$ & -1.12 & $(-1.95)$ & -1.11 & $(-1.75)$ \\
\hline $\mathbf{M T B}_{\mathrm{t}}$ & $\mathrm{a}_{9}$ & .00 & $(.01)$ & .01 & $(.45)$ \\
\hline $\mathrm{CASH}_{t} * \mathbf{M T B}_{\mathrm{t}}$ & $\mathrm{a}_{10}$ & .01 & $(.45)$ & .00 & $(-.21)$ \\
\hline STDRET $_{\mathrm{t}-1}$ & $a_{11}$ & -5.78 & $(-.82)$ & $-15.18 *$ & $(-2.18)$ \\
\hline CASH $_{t} *$ STDRET $_{t-}$ & $a_{12}$ & -15.27 & $(-1.57)$ & -4.33 & $(-.46)$ \\
\hline LSEGM $_{t}$ & $a_{13}$ & & & $-.27 *$ & $(-2.23)$ \\
\hline CASH $_{t}^{*}$ LSEGM $_{t}$ & $a_{14}$ & & & .39 & (1.24) \\
\hline FOREIGN $_{t}$ & $a_{15}$ & & & .01 & $(.05)$ \\
\hline CASH $_{t} *$ FOREIGN $_{t}$ & $\mathrm{a}_{16}$ & & & -.15 & $(-.51)$ \\
\hline $\mathbf{M A}_{\mathbf{t}}$ & $a_{17}$ & & & .12 & (.62) \\
\hline $\mathbf{C A S H}_{t}^{*} \mathbf{M A}_{t}$ & $a_{18}$ & & & -.83 & $(-1.41)$ \\
\hline RESTRUCTURE $_{\mathrm{t}}$ & $\mathrm{a}_{19}$ & & & $-.49 *$ & $(-2.75)$ \\
\hline CASH $_{t} *$ RESTRUCTURE $_{t}$ & $\mathrm{a}_{20}$ & & & 69 & (1.46) \\
\hline
\end{tabular}




\begin{tabular}{|c|c|c|c|c|}
\hline$\Delta$ SALE $_{t}$ & $a_{21}$ & & $-2.21 *$ & $(-4.30)$ \\
\hline $\mathrm{CASH}_{\mathrm{t}} * \Delta \mathrm{SALE}_{\mathrm{t}}$ & $a_{22}$ & & $1.69 *$ & $(2.18)$ \\
\hline INVT $_{t}$ & $a_{23}$ & & 1.06 & $(1.16)$ \\
\hline CASH $_{t}{ }^{*}$ INVT $_{t}$ & $a_{24}$ & & -3.57 & $(-1.41)$ \\
\hline $\mathbf{A} \mathbf{R}_{\mathbf{t}}$ & $a_{25}$ & & .46 & $(.51)$ \\
\hline $\mathrm{CASH}_{\mathrm{t}} * \mathrm{AR}_{\mathrm{t}}$ & $a_{26}$ & & -.39 & $(-.33)$ \\
\hline $\mathbf{L O S S}_{\mathbf{t}}$ & $a_{27}$ & & $.82 *$ & $(4.45)$ \\
\hline CASH $_{t} * \operatorname{LOSS}_{t}$ & $a_{28}$ & & $-.89 *$ & $(-2.51)$ \\
\hline$\Delta \mathbf{E A R N}_{t}$ & $\mathrm{a}_{29}$ & & $2.01 *$ & $(2.56)$ \\
\hline $\operatorname{CASH}_{\mathrm{t}}{ }^{*} \Delta \mathrm{EARN}_{\mathrm{t}}$ & $\mathrm{a}_{30}$ & & $-1.82 *$ & $(-2.17)$ \\
\hline$\Delta \mathbf{A L T M A N}_{\mathrm{t}}$ & $a_{31}$ & & .06 & $(.54)$ \\
\hline $\operatorname{CASH}_{t} * \Delta$ ALTMAN $_{t}$ & $a_{32}$ & & -.09 & $(-.62)$ \\
\hline $\mathbf{L A G E}_{\mathrm{t}}$ & $a_{33}$ & & -.03 & $(-.28)$ \\
\hline $\mathrm{CASH}_{\mathrm{t}} * \mathrm{LAGE}_{\mathrm{t}}$ & $a_{34}$ & & -.02 & $(-.14)$ \\
\hline B5 & $a_{35}$ & & $-.87 *$ & $(-3.87)$ \\
\hline $\mathrm{CASH}_{\mathrm{t}} * \mathrm{B5}$ & $a_{36}$ & & $.92 *$ & $(2.56)$ \\
\hline RESTATE $_{t}$ & $a_{37}$ & & -.44 & $(-1.94)$ \\
\hline CASH $_{t} *$ RESTATE $_{t}$ & $a_{38}$ & & $.97 *$ & $(2.02)$ \\
\hline $\mathbf{L E V}_{\mathbf{t}}$ & $a_{39}$ & & $.71 *$ & $(2.20)$ \\
\hline $\mathrm{CASH}_{t} * \mathrm{LEV}_{t}$ & $\mathrm{a}_{40}$ & & $-1.46^{*}$ & $(-2.81)$ \\
\hline Year Fixed Effects & & YES & YES & \\
\hline Industry Fixed Effects & & YES & YES & \\
\hline INTERCEPT & $\mathrm{a}_{0}$ & $4.65^{*}$ & $4.92 *$ & $(4.48)$ \\
\hline $\mathbf{N}$ & & 10,214 & 10,214 & \\
\hline R-sq & & .35 & .36 & \\
\hline \multirow[t]{2}{*}{ Hypotheses tests } & Coef. & $\begin{array}{l}\text { Coefficient } \quad \text { F-stat } \\
\text { Estimate }\end{array}$ & $\begin{array}{c}\text { Coefficient } \\
\text { Estimate }\end{array}$ & F-stat \\
\hline & $\mathbf{a}_{2}+\mathbf{a}_{4}$ & -5.04 & -3.65 & $(.12)$ \\
\hline
\end{tabular}


Table 4

The impact of Internal Control Weaknesses on Firms' Relation between Cash and Amihud Illiquidity

The Table summarizes estimations of models (2A) and (2B) in the paper. Each model presented reports t-statistics estimated using standard errors clustered on firm level, and includes year and industry fixed effects per Petersen (2009). All continuous variables are winsorized at the $1^{\text {st }}$ and $99^{\text {th }}$ percentiles, * denotes two-tail significance levels of .05 . All variables are defined in the Appendix.

Panel B: Impact of Section 404 Internal Control Weaknesses

\begin{tabular}{|c|c|c|c|c|c|}
\hline$D E P V A R=I L L I Q_{t}$ & & \multicolumn{2}{|c|}{ Model 2A } & \multicolumn{2}{|c|}{ Model 2B } \\
\hline Variables & Coef. & $\begin{array}{c}\text { Coefficient } \\
\text { Estimate }\end{array}$ & t-stat & $\begin{array}{c}\text { Coefficient } \\
\text { Estimate }\end{array}$ & t-stat \\
\hline ILLIQ $_{t-1}$ & $a_{1}$ & $.85^{*}$ & $(15.50)$ & $.85^{*}$ & $(15.50)$ \\
\hline $\mathrm{CASH}_{\mathrm{t}}$ & $a_{2}$ & $-5.10^{*}$ & $(-4.28)$ & -3.39 & $(-1.64)$ \\
\hline WEAK(404) & $\mathrm{a}_{3}$ & $-.86^{*}$ & $(-6.84)$ & $-.98^{*}$ & $(-6.58)$ \\
\hline CASH $_{t} *$ WEAK & $\mathrm{a}_{4}$ & $1.16^{*}$ & (3.92) & $1.27^{*}$ & (3.57) \\
\hline LMVE $_{t-1}$ & $a_{5}$ & $-.81^{*}$ & $(-11.61)$ & $-.59 *$ & $(-8.17)$ \\
\hline CASH $_{t} * L{ }^{2} E_{t-1}$ & $\mathrm{a}_{6}$ & $.70^{*}$ & $(4.88)$ & $.51^{*}$ & $(3.38)$ \\
\hline CASH $_{t} *$ INVEST $_{t}$ & $\mathrm{a}_{7}$ & $1.65^{*}$ & $(2.52)$ & $1.70^{*}$ & (2.19) \\
\hline INVEST $_{t}$ & $\mathrm{a}_{8}$ & $-1.19^{*}$ & $(-2.05)$ & -1.14 & $(-1.79)$ \\
\hline $\mathbf{M T B}_{\mathrm{t}}$ & $\mathrm{a}_{9}$ & -.00 & $(-.06)$ & .01 & $(.42)$ \\
\hline $\mathrm{CASH}_{t} * \mathrm{MTB}_{\mathrm{t}}$ & $\mathrm{a}_{10}$ & .01 & (.45) & -.00 & $(-.24)$ \\
\hline STDRET $_{\mathrm{t}-1}$ & $a_{11}$ & -5.09 & $(-.73)$ & $-14.75^{*}$ & $(-2.13)$ \\
\hline CASH $_{t} *$ STDRET $_{t-1}$ & $\mathrm{a}_{12}$ & -15.22 & $(-1.57)$ & -4.07 & $(-.44)$ \\
\hline LSEGM $_{t}$ & $\mathrm{a}_{13}$ & & & $-.25^{*}$ & $(-2.15)$ \\
\hline CASH $_{t} *$ LSEGM $_{t}$ & $\mathrm{a}_{14}$ & & & .35 & $(1.15)$ \\
\hline FOREIGN $_{t}$ & $\mathrm{a}_{15}$ & & & .04 & $(.23)$ \\
\hline CASH $_{t}$ FOREIGN $_{t}$ & $\mathrm{a}_{16}$ & & & -.22 & $(-.77)$ \\
\hline $\mathbf{M} \mathbf{A}_{t}$ & $a_{17}$ & & & .11 & $(.56)$ \\
\hline $\mathrm{CASH}_{t} * \mathrm{MA}_{\mathrm{t}}$ & $a_{18}$ & & & -.78 & $(-1.32)$ \\
\hline RESTRUCTURE $_{t}$ & $a_{19}$ & & & $-.47 *$ & $(-2.64)$ \\
\hline CASH $_{t} *$ RESTRUCTURE $_{t}$ & $\mathrm{a}_{20}$ & & & .68 & $(1.44)$ \\
\hline
\end{tabular}




\begin{tabular}{|c|c|c|c|c|c|}
\hline$\Delta \mathbf{S A L E}_{\mathrm{t}}$ & $a_{21}$ & & & $-2.23 *$ & $(-4.36)$ \\
\hline $\mathrm{CASH}_{\mathrm{t}} * \Delta \mathrm{SALE}_{\mathrm{t}}$ & $a_{22}$ & & & $1.70^{*}$ & $(2.20)$ \\
\hline INVT $_{t}$ & $a_{23}$ & & & 1.04 & $(1.14)$ \\
\hline $\mathrm{CASH}_{t} * \mathrm{INVT}_{\mathrm{t}}$ & $\mathrm{a}_{24}$ & & & -3.55 & $(-1.39)$ \\
\hline $\mathbf{A} \mathbf{R}_{\mathbf{t}}$ & $\mathrm{a}_{25}$ & & & .50 & $(.55)$ \\
\hline $\mathrm{CASH}_{\mathrm{t}} * \mathbf{A R}_{\mathrm{t}}$ & $a_{26}$ & & & -.45 & $(-.37)$ \\
\hline $\mathbf{L O S S}_{\mathrm{t}}$ & $a_{27}$ & & & $.87^{*}$ & $(4.69)$ \\
\hline $\operatorname{CASH}_{t} * \mathbf{L O S S}_{\mathrm{t}}$ & $\mathrm{a}_{28}$ & & & $-.94 *$ & $(-2.65)$ \\
\hline$\Delta$ EARN $_{t}$ & $\mathrm{a}_{29}$ & & & $2.03 *$ & $(2.60)$ \\
\hline CASH $_{t} * \Delta$ EARN $_{t}$ & $a_{30}$ & & & $-1.83 *$ & $(-2.18)$ \\
\hline$\Delta$ ALTMAN $_{t}$ & $a_{31}$ & & & .06 & $(.51)$ \\
\hline $\operatorname{CASH}_{t} * \Delta A L T M A N_{t}$ & $a_{32}$ & & & -.07 & $(-.52)$ \\
\hline LAGE $_{t}$ & $a_{33}$ & & & -.01 & $(-.12)$ \\
\hline CASH $_{t} *$ LAGE $_{t}$ & $\mathrm{a}_{34}$ & & & -.05 & $(-.28)$ \\
\hline B5 & $a_{35}$ & & & $-.89 *$ & $(-3.92)$ \\
\hline $\mathrm{CASH}_{\mathrm{t}} * \mathrm{B5}$ & $a_{36}$ & & & $.93^{*}$ & $(2.61)$ \\
\hline RESTATE $_{t}$ & $a_{37}$ & & & -.25 & $(-1.09)$ \\
\hline CASH $_{t} *$ RESTATE $_{t}$ & $a_{38}$ & & & .59 & $(1.28)$ \\
\hline $\mathbf{L E V}_{\mathrm{t}}$ & $a_{39}$ & & & $.70^{*}$ & $(2.20)$ \\
\hline $\mathrm{CASH}_{\mathrm{t}} * \mathrm{LEV}_{\mathrm{t}}$ & $\mathrm{a}_{40}$ & & & $-1.48^{*}$ & $(-2.84)$ \\
\hline Year Fixed Effects & & YES & & YES & \\
\hline Industry Fixed Effects & & YES & & YES & \\
\hline INTERCEPT & $\mathrm{a}_{0}$ & $4.83^{*}$ & $(6.95)$ & $4.94 *$ & $(4.50)$ \\
\hline $\mathbf{N}$ & & 10,214 & & 10,214 & \\
\hline R-sq & & .35 & & .36 & \\
\hline \multirow[t]{2}{*}{ Hypotheses tests } & Coef. & $\begin{array}{c}\text { Coefficient } \\
\text { Estimate }\end{array}$ & F-stat & $\begin{array}{c}\text { Coefficient } \\
\text { Estimate }\end{array}$ & F-stat \\
\hline & $\mathbf{a}_{2}+\mathbf{a}_{4}$ & $-3.94 *$ & (15.37) & $-2.12 *$ & (12.73) \\
\hline
\end{tabular}


Variable Descriptions: $\boldsymbol{A C A S H}=$ The change in cash $(\triangle \mathrm{Cash} /$ Assets $)$; WEAK (302/404) $=1$ if Audit Analytics reports Section302 (or Section 404) ICW any of the years t, t-1, or t-2, = 0 otherwise; $\boldsymbol{C F O}=($ Operating Cash Flow)/Assets; $\boldsymbol{L M V E}$ $=\log$ (Market Value of Equity); $\boldsymbol{L A G E}=\log ($ firm age $) ; \boldsymbol{T O B I N}=($ Tobin's Q), defined as (Market Value of Equity + Liabilities) / (Book Value of Equity + Liabilities); ILLIQ = (Amihud Illiquidity), defined as annual average of daily ratio of absolute value of daily CRSP stock returns to dollar volume: $\mid$ Ret $/($ dollar volume $) ; \boldsymbol{I N V E S T}=($ Capital Expenditures + Research \& Development Costs) / Assets; MTB = Market-to-book ratio; STDRET = Standard deviation of daily CRSP stock returns; $\boldsymbol{L E} \boldsymbol{V}=$ Total Liabilities/ Total Assets; $\boldsymbol{L O S S}=1$ if ROA $<0,=0$ otherwise; $\boldsymbol{L S E \boldsymbol { G }}=$ Natural log of the number of segments (Compustat); FOREIGN $=1$ if a firm reports income from foreign operations, $=0$ otherwise; $\boldsymbol{M A}=1$

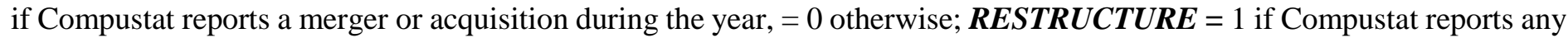

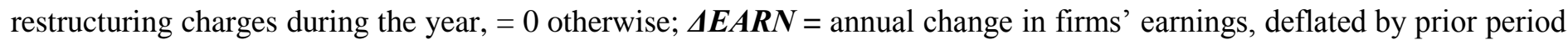
total assets; $\triangle \boldsymbol{A L T M A N}=$ Percentage change in a firm's Altman Z-Score; $\boldsymbol{B 5}=1$ if a firm is a Big N firm,= 0 otherwise; $\boldsymbol{C A S H}=$ Firm's Cash balance (CHE) deflated by prior period assets; $\boldsymbol{\Delta S \boldsymbol { A } \boldsymbol { E }}=$ Annual change in firms sales deflated by prior period assets; $\boldsymbol{I N V \boldsymbol { T }}=$ Inventory $/$ Assets; $\boldsymbol{A R}=($ Accounts Receivable) $/$ Assets; $\boldsymbol{R E S T A T E}=1$ if a firm had a restatement indicated in Audit Analytics, $=0$ otherwise. 